\title{
REDUCTION OF DISINFECTION BY-PRODUCTS IN NATURAL WATERS USING NANOFILTRATION MEMBRANES
}

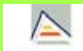 \\ Sentana, I.; Rodríguez ,M.; Sentana, E.; C. M’Birek and Prats, D. \\ University of Alicante. Water and Environmental Science Institute. \\ P.0. Box 99. 03080 Alicante, Spain e-mail: irene.sentana@ua.es
}

\section{NTRODUCTION}

In the Mediterranean region, the availability of water many times does not meet the demand on existing resources in terms of quantity and quality owing to the scarce rainfall there. Many of the sources of natural water used for supplying the local population contain considerable amounts of Natural Organic Matter. The NOM found in the water can react with Chlorine to form Disinfection By-products such as trihalomethanes, haloacetic acids, etc. that deteriorate the water quality, rendering it unfit for human consumption because it could lead to adverse health effects [1]

This investigation involved the study of THM and HAA formation potential by nanofiltration. Natural waters from two different sources in Alicante province were analyzed. The study was carried out using three commercial NF membranes denoted by NF-270, NF- 90 and Desal-HL-51. The influence of conductivity was also analyzed.

\section{MATERIALS}

EQUI PMENT: Nanofiltration experiments were carried out in a stirred cell apparatus (Model 8200 Amicon Millipore).

- MEMBRANES: Three NF membranes (NF 90, NF270 and Desal-HL-51) obtained from Dow-Filmtec and Osmonics were used. Membranes had a diameter of $63.5 \mathrm{~mm}$.

- FEED WATER: Two different waters were tested; Amadorio and Pedrera

reservoirs. Both are situated in southeast Spain, in the Alicante province

Conductivity: $1000-6000 \mu \mathrm{S} / \mathrm{cm}$ adjusted by addition of $\mathrm{NaCl}(0.1 \mathrm{M})$.

- ANALYTI CAL METHODS

A simulated chlorination, using method 5710B, "Standard Methods for the examination of Water and Wastewater", was carried out to determine the formation potentials of THM and HAA. A chlorine dosis of $20 \mathrm{mg} / \mathrm{L}$ was employed [2]

The THMs and HAAs formed were determined by the USEPA 551.1 and USEPA 552.2 method.

\section{METHODS}

\section{- FI LTRATI ON PROTOCOL}

$1^{\circ}$ STEP: Stirred cell was initially filled with DI water and in every experiment conductivity and pressure were adjusted

$2^{\circ}$ STEP: The water flux was measured as a function of time at a constant pressure ( 3 bar), until steady flux was achieved.

3० STEP: Stirred cell was emptied and refilled with reservoirs water and the system was repressurized. The filtrate flow rate was measured. Permeate samples were collected periodically for subsequent concentration analysis.

$4^{\circ}$ STEP: Stirred cell was emptied and refilled with DI water at the same $\mathrm{pH}$, conductivity and pressure, as the initial experiment.

Note: In all experiments the stirring speed was fixed to $200 \mathrm{rpm}$. Temperature $20^{\circ} \mathrm{C}$ Conductivity was adjusted to following ranges : $1000-6000 \mu \mathrm{S} / \mathrm{cm}$.

\section{- VARIATI ON OF THE PERMEATE FLOW-RATE}

\section{RESULTS AND DISCUSSION}

The largest drop in flow-rate was produced by the NF-90 membrane and the smallest, by the Desal-HL-51, using treated water from both reservoirs.

All of the membranes produce a large initial drop in flow-rate with water from the Pedrera versus Amadorio reservoir; this could be due to the higher DOC content of the Pedrera, and the slightly lower MWCO of the organic material in its waters as compared to the Amadorio's, which allows it to enter pores much easier, blocking them to a greater extent and producing a greater drop in flow-rate as a consequence.

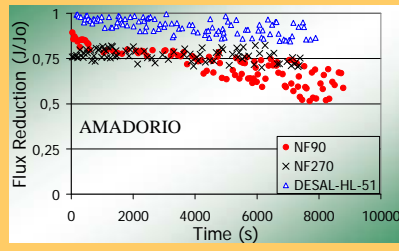

$$
\text { Figure 1. Flux reduction versus time }
$$

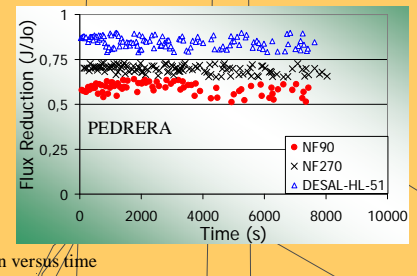

\section{- CONDUCTIVITY EFFECTS}

For all of the membranes, an increase in conductivity implies a large drop in permeate flow-rate. This effect is largest when using the NF 90 and Desal HL-51
membranes.

The analyses carried out on THMFP and HAAFP do not reveal important trends in terms of the results achieved by adjusting the conductivity. Therefore, the results of all experiments resemble those in which the water retains its original conductivity
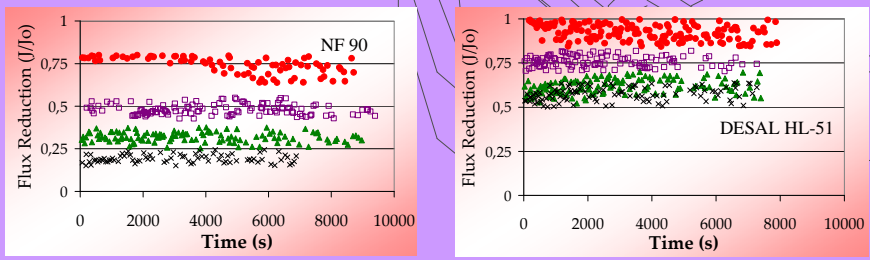

Figure 3. Flux reduction versus time. Conductivity. Amadorio Reservoir $\bullet 700 \square 2000 \wedge 4000 \times 6000 \mu \mathrm{S} / \mathrm{cm}$

\section{- REFERENCES}

Xiang, Hong. Lu, Xi-wu. Study advance on carcinogenicity of haloacetic acids in drinking water. Anquan Yu Huanjing Gongcheng (2008), 15(1), 17-21. CODEN: AYHGAJ ISSN:1671-1556. AN 2008:780609 CAPLUS

Rodriguez Vidal, Francisco Javier. Procesos de potabilización del agua e influencia del tratamiento de ozonización. ISBN: 978-84-7978-587Editorial: Díaz de Santos SA. 2003

45/2003, de 21 febrero $(7228-7245)$

\section{- ACKNOWLEDGEMENT}

2010 CTQ2007-66780 by the Spanish Government.

\section{REJ ECTI ON OF THMPF AND HAAPF}

The total amount of THMFP in the original sample from the Pedrera reservoir, and, in fact, even individual THM concentrations, are much higher than for samples from the Amadorio reservoir.

All the membranes studied, the NF-90 membrane most reduces the THMFP. This reduction is matched by the greatest drop in flow rate and the lowest MWCO of all the membranes. As a consequence, the membrane produces a greater sifting effect.

Regarding HAAFP, MCAA and MBAA formed in practically none of the water samples. DCAA, however, did appear in elevated quantities. The concentration of HAAFP is in general higher in water from the Amadorio versus Pedrera reservoir, the opposite of what would occur in the case of THMFP.
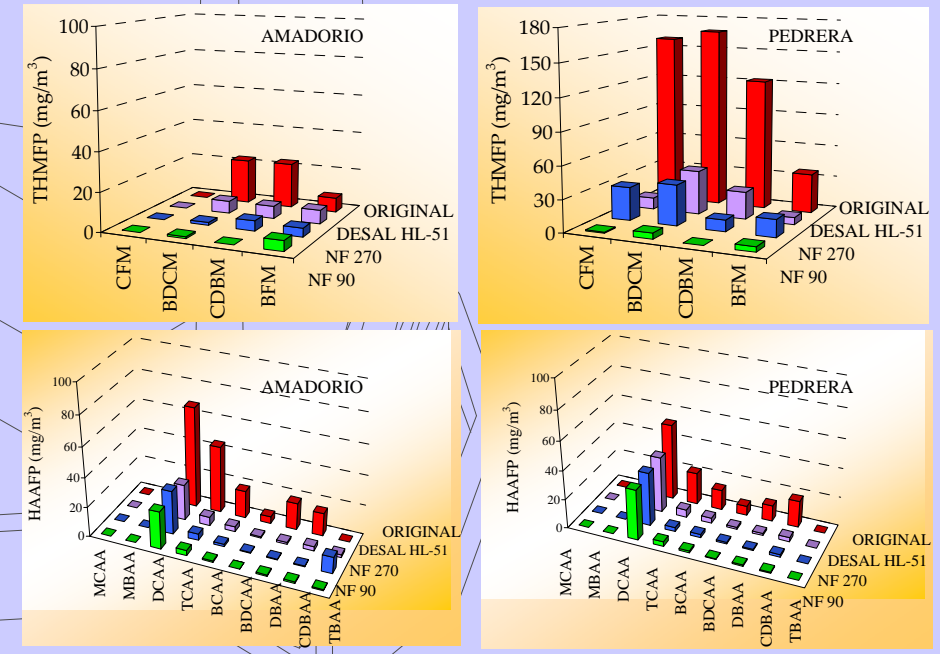

Fig 2. THMPF and HAAPF concentration from original and nanofiltration permeates obtained from the different membrane

\section{- CONCLUSION}

- Of all the water samples, those treated using the Desal-HL-51 membrane display a minimum drop in permeate flow-rate, below $25 \%$. The membrane that produces the greatest drop in flow-rate is in all cases the NF-90.

- With regard to reductions in the formation of THMFP and HAAFP, the NF-90 membrane exhibits the best performance, obtaining in the case of THMs concentrations that are within all officially mandated limits [3], the same trend happens in the case of HAAs, whose concentrations no exceed the upper limits established under current US legislation.

- Increases in conductivity do not affect the capacity of membranes to limit the formation of HAAs or THMs. An increase in conductivity in general produces a greater drop in flow-rate. 